\title{
Environmental variables in packing houses and their effects on the quality of grapes
}

\author{
Osvaldo C. Vasconcelos ${ }^{1}$, Cristiane Dacanal ${ }^{2}$, Sílvia H. N. Turco ${ }^{1}$, \\ Sergio T. Freitas ${ }^{3}$, Clóvis M. C. Ramos $^{1} \&$ Paula M. L. de Lima ${ }^{2}$ \\ ${ }^{1}$ Universidade Federal do Vale do São Francisco/Departamento de Engenharia Agrícola. Juazeiro, BA. E-mail: eng.osvaldocampelo@hotmail.com \\ (Corresponding author); silvia.turco@univasf.edu.br; clovis.ramos@univasf.edu.br \\ ${ }^{2}$ Universidade Federal do Vale do São Francisco/Departamento de Engenharia Agronômica. Petrolina, PE. E-mail: cristiane.dacanal@univasf.edu.br; \\ paulamaria_lima@hotmail.com \\ ${ }^{3}$ Empresa Brasileira de Pesquisa Agropecuária/Embrapa Semiárido/Laboratório de Fisiologia e Tecnologia Pós-Colheita. Petrolina, PE. E-mail: \\ sergio.freitas@embrapa.br
}

Key words:

ambience

spatial distribution

post harvesting

\begin{abstract}
A B S T R A C T
The aim of this study was to characterize the thermal environment in the selection and packing areas of a packing house and its effects on the quality of table grapes produced in the São Francisco Valley, Brazil. The thermal environment was monitored during the winter and summer seasons. The highest value of air temperature (Tair) and the lowest relative humidity (RH) observed in the packing house were $35^{\circ} \mathrm{C}$ and $40.0 \%$, respectively, obtained during the summer, for $8 \mathrm{~h}$. After observing the thermal environment data of the packing house, simulations were performed to evaluate the effect of the ideal environmental storage conditions and observed thermal conditions on the postharvest quality of "Thompson" grapes. Grapes were harvested and stored directly at the ideal temperature and $\mathrm{RH}$ of $0{ }^{\circ} \mathrm{C}$ and $90 \%$, respectively, or previously exposed to a temperature of $35^{\circ} \mathrm{C}$ and $\mathrm{RH}$ of $40 \%$ for $8 \mathrm{~h}$, the thermal environment observed in the evaluated packing house, followed by storage at $0{ }^{\circ} \mathrm{C}$ and $90 \% \mathrm{RH}$. Fruit exposure to high temperature and low $\mathrm{RH}$ before the ideal storage conditions resulted in higher loss of berry firmness and weight, along with increased soluble solids and dry matter content of rachis and berry. Based on these results, the environmental conditions observed in the packing house result in berry dehydration, which accelerates the loss of fruit quality during storage.
\end{abstract}

\section{Palavras-chave:}

ambiência

espacialização

pós-colheita

\section{Variáveis ambientais em 'packing houses' e efeitos sobre a qualidade de uvas}

\section{R E S U M O}

Objetivou-se caracterizar o ambiente térmico da área de seleção e embalagem de um 'packing house' e seus efeitos sobre a qualidade de uvas de mesa produzidas no Vale do São Francisco. O ambiente térmico foi monitorado durante as estações de inverno e verão. Os maiores valores de temperatura do ar (Tar) e menores de umidade relativa do ar (UR) observados no packing house, foram $35^{\circ} \mathrm{C}$ e $40,0 \%$, respectivamente, obtidos durante o verão, por $8 \mathrm{~h}$. Após a observação dos dados do ambiente térmico do packing house, foram feitas simulações para avaliar o efeito de condições ambientais ideais de armazenamento e das condições térmicas observadas sobre a qualidade pós-colheita de uvas 'Thompson'. Neste contexto, uvas foram colhidas e diretamente armazenadas em temperatura e umidade ideais $\left(0^{\circ} \mathrm{C}\right.$ e $\left.90 \%\right)$, ou foram expostas previamente a uma temperatura do ar de $35^{\circ} \mathrm{C}$ e umidade relativa do ar de $40 \%$ por $8 \mathrm{~h}$, simulando o ambiente térmico observado no packing house avaliado, sendo posteriormente armazenada a $0{ }^{\circ} \mathrm{C}$ e $90 \%$. A exposição dos frutos ao ambiente observado no packing house resultou em maiores perdas de firmeza e peso de bagas, assim como aumentou os teores de sólidos solúveis e matéria seca do engaço e da baga. De acordo com os resultados obtidos, as condições ambientais observadas no packing house resultam na desidratação das bagas, acelerando a perda de qualidade dos frutos durante o armazenamento. 


\section{INTRODUCTION}

The Vitis vinifera L. species is distinguished by its economic importance and high morphological and genetic diversity. In the lower part of the São Francisco River Valley Basin in Brazil, viticulture is concentrated on the $V$. vinifera L. species, and the main genotypes produced in the region are the cultivars Italia, Benitaka, Red Globe, Sugraone, Thompson Seedless, and Crimson Seedless (Mascarenhas et al., 2013; Santos et al., 2015).

According to various studies, daily losses occurring in packing houses in the region of Petrolina-PE and Juazeiro-BA reach up to $3.9 \%$ (Ribeiro et al., 2014). A substantial amount of the postharvest losses is due to the lack of fast cooling of fruit after harvesting. The studies report that longer the time between picking and cooling, the higher the quality loss (Guillou, 1958; Gibbon, 1972; Nunes et al., 1995; Sullivan et al., 1996; Brackmann et al., 2002; Mitchell, 2002; Teruel, 2008).

For table grapes, it is recommended to maintain the temperature and relative humidity $(\mathrm{RH})$ of the fruits at $0{ }^{\circ} \mathrm{C}$ and 90-95\%, respectively, after harvesting (Chitarra \& Chitarra, 2005; Lima, 2016). Variations in the recommended temperature and humidity may exist, depending on the genotype that will be stored (Brackmann et al., 2002). The technologies for fast cooling allows the formation of a cold chain associated with rapid lowering of the temperature, which can significantly remove the heat load of the product after harvesting, thus reducing the metabolism, maintaining quality, and increasing the fruit postharvest life (Teruel, 2008).

The studies recommend that the selection and packaging areas in table grape packing houses should be kept at $20^{\circ} \mathrm{C}$, with the RH of 90-95\% (Soares \& Leão, 2009).

Therefore, the aim of this study was to characterize the thermal environment in the selection and packaging areas of a packing house and its effects on the quality of table grapes produced in the São Francisco Valley, Brazil.

\section{Material ANd Methods}

For the thermal analysis of the packing house environment at the ST farm in Petrolina, PE, located in the São Francisco Valley, the installation was measured with a Fluke 424D Laser Distance Meter (Fluke Corporation, Washington, USA) to generate the planimetric survey of the building. The data collection took place in June 2014, and in January and February 2015.

The installation is subdivided into reception, selection, and packaging, with an area of $92 \mathrm{~m}^{2}$ (the studied sector), and shipping, quality control, packaging, administration and access, for a total area of $232 \mathrm{~m}^{2}$. It is located in zone $24 \mathrm{~L}$ of the north-south magnetic axis.

The environment studied contains hedges along the outer sides (east and west) of the packing house, which is located at $9^{\circ} 17^{\prime} 34^{\prime \prime} \mathrm{S}, 40^{\circ} 29^{\prime} 01^{\prime \prime} \mathrm{O}$, with altitude of $400 \mathrm{~m}$. It has a small size, with length of $13.6 \mathrm{~m}$, width of $6.75 \mathrm{~m}$, ceiling height of $4.0 \mathrm{~m}$, and ridge height of $5.5 \mathrm{~m}$. The building has galvanized tile roof, ceramic brick blocks, brown metal gates, and external and internal mortar coating. The exterior of the facility is painted in yellow, and the inside has white ceramic tile on the walls and a gravel dust floor (Vasconcelos, 2015).

The air temperature data were taken within a grid of points spaced $2 \times 2 \mathrm{~m}^{2}$ distributed in the packing house forming an $\mathrm{X}$ and $\mathrm{Y}$ Cartesian plane, totalizing twenty points. The collection was carried out on five nonconsecutive days (5 repetitions) referred to as times. The temperature measurement was performed with a TAD 500 thermo anemometer (Instrutherm, São Paulo, Brazil) throughout the installation.

The data collection was used to generate a temperature distribution map of the packing house reception area. The temperature data were evaluated with the aid of an electronic spreadsheet to obtain statistical data. A geostatistical analysis and adjustment of the theoretical semivariograms were then carried out using the Gs+ software (Rockware, Golden, USA). With the variograms, interpolation was performed by ordinary kriging to generate temperature maps for the selection area of the installation at $10 \mathrm{am}$, and 1:00 and 3:00 pm, during the winter and summer seasons. The $\mathrm{RH}(\%)$ was assessed using HOBO H12 data loggers (Onset, Bournemouth) located at twenty points distributed throughout the selection area of the facility, arranged at a height of $1 \mathrm{~m}$ in a $3 \times 3 \mathrm{~m}^{2}$ grid.

For analyzing the environmental characteristics, the exposition time of the fruit to temperature and humidity of the location was observed. Thus, based on the obtained information, the effects of environmental conditions, including highest and lowest temperatures, on the physicochemical characteristics of the fruit during storage were evaluated.

To analyze the quality of the fruit after passage through the packing house selection area, the same thermal conditions observed in the analyzed packing house were simulated at the Embrapa Semi-Arid Postharvest Physiology Laboratory. After harvesting, table grapes (var. Thompson) were submitted to two storage conditions: first, fruits harvested and stored at $0{ }^{\circ} \mathrm{C}$ and 90-95\% RH (TCA) (Brackmann, 2002; Teruel, 2008; Lima, 2016). Second, fruits stored at the elevated temperatures that were observed in the analyzed packing house, $35^{\circ} \mathrm{C}$ and $40 \%$ $\mathrm{RH}$ for $8 \mathrm{~h}$, and then stored at $0{ }^{\circ} \mathrm{C}$ and $90-95 \% \mathrm{RH}$ (TER).

The experiment was carried out in a completely randomized design, and each treatment consisted of four repetitions with $400 \mathrm{~g}$ of fruit each. Evaluations were performed at 0, 14, 30, and $30+7$ days, and during the last 7 days the conditions were $25^{\circ} \mathrm{C}$ and $90-95 \% \mathrm{RH}$, simulating the fruit shelf life. The fruits were evaluated for physicochemical parameters such as abscission, abscission resistance, skin color, berry firmness, decay incidence, soluble solids, titratable acidity, weight loss, rachis and berry dry matter, and rachis browning.

The harvesting of berries for the physicochemical assessments was performed on the opposite sides of the bunch, collecting two berries in the upper region, two in the middle, and two in the lower region.

The berry abscission was expressed as a percentage, obtained by multiplying the weight of loose berries by 100 and dividing this by the total berry weight, for each sample. 
Abscission resistance was quantified with an Extralab Brazil digital texturometer, Model TA.XT (Stable Micro Systems, Jarinu, Brazil) coupled to a system for determining the abscission tension. The tip of a steel spring $6 \mathrm{~cm}$ long and $0.8 \mathrm{~cm}$ in diameter was fixed to the equipment reading arm. The device was programmed so that the upward movement of the reading arm was positioned on the longitudinal axis of the berry pedicel. The tension reading mode used a test speed of $2 \mathrm{~mm} \mathrm{~s}^{-1}$ and readings were obtained representing the maximum peak tension required for the complete separation of the pedicel from the berry.

The epidermis color was determined via the CIE Lab system with a Minolta CR 400 colorimeter (Konica Minolta, Ramsey, USA) where $L^{*}$ is the lightness, which varies from white (highest value) to black (lowest value), $\mathrm{a}^{*}$ ranges from green (lowest value) to red (highest), and $b^{\star}$ ranges from blue (lowest value) to yellow (highest).

Berry firmness $(\mathrm{N})$ was determined in the equatorial region of six individual berries with the aid of an Extralab Brazil model TA.XT plus digital texturometer (Stable Micro Systems, Jarinu, Brazil). A 75-mm-diameter probe was used, with a contact area of $4417.86 \mathrm{~mm}^{2}$, pretest speed of $5 \mathrm{~mm} \mathrm{~s}^{-1}$, test speed of $1 \mathrm{~mm} \mathrm{~s}^{-1}$, post-test speed of $15 \mathrm{~mm} \mathrm{~s}^{-1}$, and activation force of $0.98 \mathrm{~N}$.

Rot incidence (\%) was determined by multiplying the total number of affected berries by 100 and dividing this by the total number of berries in the sample.

For the soluble solids (SS) and tartaric acid concentration evaluation, a portion of juice removed from six berries per replicate was used. The SS were determined with the aid of an Atago PAL-1 3810 portable digital refractometer (Atago, Diadema, Brazil) and expressed as a percentage. The concentration of tartaric acid was determined in a solution of $5 \mathrm{~g}$ of the juice diluted in $50 \mathrm{~mL}$ of distilled water, titrated with a Titrino 848 Plus automatic titrator (Metrohm, Sao Paulo, Brazil) using $0.1 \mathrm{~N} \mathrm{NaOH}$ as titrant; data were expressed as percentage (\%) of tartaric acid (AOAC, 2012).

The fruit weight loss was determined by weighing the samples in each storage period; the results were expressed in percentage of weight loss based on (100\%) initial sample weight (Silva et al., 2012).

The dry matter of stems and berries were determined by weighing the fresh samples and the same samples after drying at $60{ }^{\circ} \mathrm{C}$, until constant weight was achieved. The dry matter percentage was obtained by multiplying the dry weight by 100 and dividing by the sample fresh weight.

Stem browning was determined using a subjective scale (0-4), where 0 is no rachis darkening; 1 represents the onset of darkening of the pedicel region (to $50 \%$ complete) or the rachis apex; 2 indicates darkening of the pedicel region, from the apex up to $10 \%$ of the principal axis of the rachis; 3 represents a total darkening of the pedicel region and the apex, and 50\% of the principal axis of the rachis; and 4 denotes the darkening of the pedicel, the apex, and more than $50 \%$ of the main axis (Pinto et al., 2015).

The variables were submitted to variance analysis using the software ASSISTAT, version 7.7 (Silva \& Azevedo, 2016), and the means were compared using Tukey's test at $5 \%$ of probability.

\section{RESUlTS AND Discussion}

Based on the adjusted theoretical variogram parameters, maps of the spatial variation of temperature were made using ordinary kriging. It can be seen that for all evaluated times and seasons, the $\mathrm{R}^{2}$ coefficients of the spatial models of variations were above $85 \%$, which indicates less errors in map generation (Table 1).

The temperature variation maps at 10 am and $1 \mathrm{pm}$ in the winter season (Figures $1 \mathrm{~A}$ and $\mathrm{B}$ ) show a region with higher temperature in the receiving gate area of the packing house. Although this sector has a gravel cover, the brown-painted metallic gate possibly provided the heat. The fact that the warmest air pocket is in the east of the building indicates that direct impact of solar radiation on the surfaces causes the warming, despite the hedge around the installation.

In the summer, at 10:00 am, the interior of the installation presents a maximum temperature of $29.5^{\circ} \mathrm{C}$ and minimum of $28{ }^{\circ} \mathrm{C}$ (Figure 1D).

According to the temperature layout at 1:00 pm in the summer, the solar radiation caused warming in the receiving area and the area close to the fans, blowing hot air from the roof into the facility (Figure 1E).

Owing to the north-south orientation of the studied packing house, a hedge was used in order to reduce the thermal load originating from sunlight reaching the installation; however, there was little effect on the environment. The corresponding data do not corroborate those from the studies realized by Matheus et al. (2016), which showed that this technique was able to provide an average thermal dampening of up to $19^{\circ} \mathrm{C}$ and an average delay of four hours in the hottest times of the day, on a masonry surface in the city of Campinas-SP, Brazil, during the summer.

The inversion observed in the temperature variation between the northern and southern part of the construction at 3:00 pm in winter (Figure 1C) occurs in a similar manner in summer at the same time, but at higher temperatures (Figure $1 F)$, with an evident rise in temperature throughout the environment, confirming the statement above. As the southern area of the building, near the fruit receiving area, does not have ground cover, much of the radiation is absorbed by the soil and is radiated into the building at warmer periods (reflected).

The studies also show that the use of shed ventilation devices is advantageous for ventilation via wind action,

Table 1. Values of the packing house air temperature variograms at 10:00 am, and 1:00 and 3:00 pm in winter and summer seasons in a packing house at the São Francisco Valley

\begin{tabular}{lccccc}
\hline $\begin{array}{c}\text { Packing } \\
\text { house }\end{array}$ & Model & $\mathbf{C}_{0}$ & $\mathbf{C}_{\mathbf{0}}+\mathbf{C}$ & $\mathbf{A}$ & $\mathbf{R}^{2}$ \\
Winter & Exponential & \multicolumn{2}{c}{ Temperature at 10:00 am } \\
Summer & Gaussian & 0.0064 & 0.0886 & 2.31 & 0.94 \\
\hline \multicolumn{5}{c}{ Temperature at 1:00 pm } \\
Winter & Spherical & 0.0127 & 0.0764 & 14.95 & 0.87 \\
Summer & Spherical & 0.0640 & 0.4070 & 9.77 & 0.98 \\
\hline \multicolumn{7}{c}{ Temperature at 3:00 pm } \\
Winter & Gaussian & 0.0141 & 0.0223 & 11.16 & 0.98 \\
Summer & Gaussian & 0.0001 & 0.0273 & 21.8 & 0.99 \\
\hline
\end{tabular}

$\mathrm{C}_{0}$ - Nugget effect; $\mathrm{C}_{0}+\mathrm{C}$ - Baseline; $\mathrm{A}$ - Range; $\mathrm{R}^{2}$ - Correlation coefficient 

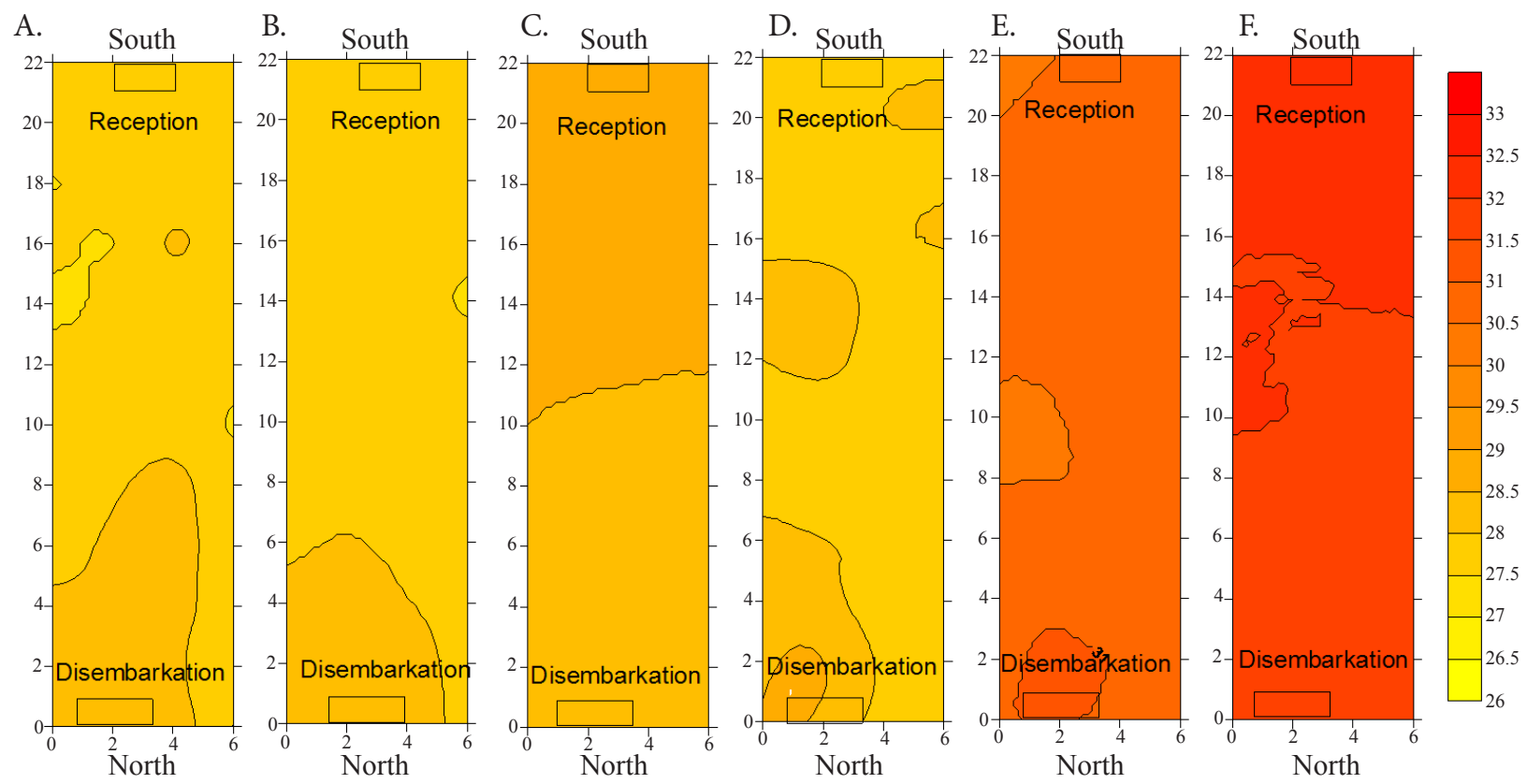

Figure 1. Analysis in temperature $\left({ }^{\circ} \mathrm{C}\right)$ of kriging in the packing house selection areas at 10:00 am (A), 1:00 pm $(\mathrm{B})$, and 3:00 pm (C) in the winter, and 10:00 am (D), 1:00 pm (E), and 3:00 pm (F) in the summer

providing greater airflow and reducing the internal temperature. This may be a solution for reducing the temperature in the packing house (Lukiantchuki et al., 2016). Such devices operate by incorporating natural ventilation for indoor environments, thus providing greater air movement within the building.

In both the winter and summer seasons, environmental temperature conditions above the recommended, and $\mathrm{RH}$ below the recommended for packing houses dealing with fruit, such as table grapes, were observed (Soares \& Leão, 2009). The cited environmental conditions (Table 2) can result in losses in postharvest fruit quality during storage.

The results show that fruits submitted to TER have high qualitative and quantitative losses during the storage and commercialization period. It is through this fact that the quality characteristics of the fruits submitted to these conditions (as observed by the regionalized maps) were analysed.

According to the results, the evaluated variables: abscission, berry resistance to abscission, rachis browning index, epidermis color $\left(\mathrm{L}^{\star}, \mathrm{a}^{\star}, \mathrm{b}^{\star}\right)$, and tartaric acid showed no significant difference between fruits harvested and stored at $0{ }^{\circ} \mathrm{C}$ with $90 \% \mathrm{RH}$ and fruits exposed to a temperature of $35^{\circ} \mathrm{C}$ and $\mathrm{RH}$ of $40 \%$ for $8 \mathrm{~h}$ prior to cold storage.

As for the studied variables: berry firmness, weight loss, soluble solids, rachis dry matter, and berry dry matter were statistically significant (Table 3 ).

Table 2. Relative humidity $(\mathrm{RH})$ of the packing house at 10:00 am, and 1:00 and 3:00 pm in the winter and summer seasons in a packing house at the São Francisco Valley, Brazil

\begin{tabular}{lccc}
\hline & & Winter \\
Time & $10: 00 \mathrm{am}$ & $1: 00 \mathrm{pm}$ & $3: 00 \mathrm{pm}$ \\
$\mathrm{RH}(\%)$ & 61.0 & 54.3 & 51.2 \\
\hline & & Summer & \\
Time & $10: 00 \mathrm{am}$ & $1: 00 \mathrm{pm}$ & $3: 00 \mathrm{pm}$ \\
RH (\%) & 55.4 & 44.4 & 40.0 \\
\hline
\end{tabular}

The berry firmness decreased during storage. Fruits exposed to the recommended temperature and moisture after harvest maintained higher berry firmness throughout the storage, compared to fruits exposed to high temperature and low RH after harvest (Table 3).

A similar study shows that table grape exposure to $25^{\circ} \mathrm{C}$ and $95 \% \mathrm{RH}$ for $24 \mathrm{~h}$ shortly after harvest, followed by refrigerated storage, accelerates the loss of fruit pulp firmness, compared to fruit stored in a refrigerated environment shortly after harvest (Wu et al., 2015). In both studies, fruit exposure to high temperature and low $\mathrm{RH}$ possibly accelerated the metabolism and increased the activity of enzymes that degrade the cell wall, accelerating fruit softening during storage.

Data that emphasize the presented result were obtained with 'Flame Seedless' grapes, for which the firmness of the fruits stored at $3{ }^{\circ} \mathrm{C}$ and $90 \% \mathrm{RH}$ for up to 75 days was evaluated. It was observed that as berry firmness decreased during storage, the concentration on the cell wall of degrading enzymes, such as pectin methylesterase, pectin esterase, and polygalacturonase increased significantly. It was also noted that when the firmness of berries is high, they exhibit less activity of the pectin methylesterase enzyme (Champa et al., 2015).

Weight loss increased in all treatments throughout the experiment. The highest weight loss was observed in fruits exposed to high temperature and low $\mathrm{RH}$ after harvest (Table 3). During the last seven days at $25^{\circ} \mathrm{C}$, the weight loss value increased three times, possibly owing to the temperature increase, which also influenced the increase in fruit respiration rate that leads to a higher water and $\mathrm{CO}_{2}$ loss. Similar results were observed for 'Italia' grapes stored at $21.2\left( \pm 1.6^{\circ} \mathrm{C}\right)$ for 9 days, which resulted in a weight loss of $0.73 \%$ per day (Albertini et al., 2009).

The available studies have shown that weight loss is higher in grapes kept at $25{ }^{\circ} \mathrm{C}$ compared to grapes kept at $12{ }^{\circ} \mathrm{C}$ (Silva et al., 2012; Sabir \& Sabir, 2013), as in the case of Dona Zilá grapes (Brackmann et al., 2002). The present study is 
Table 3. Quality attributes of 'Thompson' grapes stored after harvesting at $0{ }^{\circ} \mathrm{C}$ and $90 \% \mathrm{RH}$ or exposed to $35{ }^{\circ} \mathrm{C}$ and $40 \% \mathrm{RH}$ for eight hours followed by refrigerated storage at $0{ }^{\circ} \mathrm{C}$ and $90 \% \mathrm{RH}$

\begin{tabular}{|c|c|c|c|c|}
\hline \multirow{2}{*}{ Treatment } & \multicolumn{4}{|c|}{ Days } \\
\hline & 0 & $\overline{14}$ & 30 & $30+7$ \\
\hline & \multicolumn{4}{|c|}{ Berry firmness $(\mathrm{kg})$} \\
\hline $0^{\circ} \mathrm{C}+\mathrm{RH} 90-95 \%$ & $9.6 \pm 2.2 a^{*}$ & $10.1 \pm 1.5 \mathrm{a}$ & $4.9 \pm 0.9 a$ & $4.7 \pm 0.8 \mathrm{a}$ \\
\hline $35^{\circ} \mathrm{C}+\mathrm{RH} 40 \%+8 \mathrm{H}$ & $9.6 \pm 2.2 \mathrm{a}$ & $7.6 \pm 1.3 b$ & $3.3 \pm 0.3 b$ & $3.4 \pm 0.4 b$ \\
\hline \multirow[t]{2}{*}{ CV (\%) } & 22.09 & 15.22 & 16.26 & 16.17 \\
\hline & \multicolumn{4}{|c|}{ Weight loss (\%) } \\
\hline $0^{\circ} \mathrm{C}+\mathrm{RH} 90-95 \%$ & $0.19 \pm 0.06 b$ & $1.6 \pm 0.13 b$ & $2.7 \pm 0.17 b$ & $5.6 \pm 0.24 b$ \\
\hline $35^{\circ} \mathrm{C}+\mathrm{RH} 40 \%+8 \mathrm{H}$ & $2.00 \pm 0.41 \mathrm{a}$ & $4.0 \pm 0.92 \mathrm{a}$ & $4.8 \pm 0.97 a$ & $8.2 \pm 1.31 \mathrm{a}$ \\
\hline \multirow[t]{2}{*}{ CV (\%) } & 26.5 & 23.68 & 18.41 & 13.67 \\
\hline & \multicolumn{4}{|c|}{ Soluble Solids (\%) } \\
\hline $0^{\circ} \mathrm{C}+\mathrm{RH} 90-95 \%$ & $21.5 \pm 0.78 a$ & $21.1 \pm 0.80 a$ & $21.3 \pm 0.89 a$ & $19.9 \pm 0.96 b$ \\
\hline $35^{\circ} \mathrm{C}+\mathrm{RH} 40 \%+8 \mathrm{H}$ & $21.5 \pm 0.78 a$ & $21.6 \pm 0.25 a$ & $21.3 \pm 1.29 a$ & $22.4 \pm 0.46 a$ \\
\hline \multirow[t]{2}{*}{ CV (\%) } & 3.62 & 2.76 & 5.19 & 3.54 \\
\hline & \multicolumn{4}{|c|}{ Rachis dry matter (\%) } \\
\hline $0^{\circ} \mathrm{C}+\mathrm{RH} 90-95 \%$ & $37.1 \pm 1.85 a$ & $37.8 \pm 1.84 b$ & $38.7 \pm 2.17 b$ & $44.2 \pm 5.47 b$ \\
\hline $35^{\circ} \mathrm{C}+\mathrm{RH} 40 \%+8 \mathrm{H}$ & $37.1 \pm 1.85 \mathrm{a}$ & $43.4 \pm 2.42 \mathrm{a}$ & $46.5 \pm 1.18 \mathrm{a}$ & $51.6 \pm 1.16 \mathrm{a}$ \\
\hline \multirow[t]{2}{*}{ CV $(\%)$} & 4.98 & 5.29 & 4.1 & 8.25 \\
\hline & \multicolumn{4}{|c|}{ Berry dry matter (\%) } \\
\hline $0^{\circ} \mathrm{C}+\mathrm{RH} 90-95 \%$ & $23.0 \pm 1.26 \mathrm{a}$ & $23.4 \pm 1.96 a$ & $22.8 \pm 1.07 \mathrm{a}$ & $20.8 \pm 1.22 b$ \\
\hline $35^{\circ} \mathrm{C}+\mathrm{RH} 40 \%+8 \mathrm{H}$ & $23.0 \pm 1.26 \mathrm{a}$ & $22.6 \pm 1.37 \mathrm{a}$ & $22.7 \pm 2.42 \mathrm{a}$ & $22.8 \pm 0.71 \mathrm{a}$ \\
\hline CV (\%) & 5.46 & 7.34 & 8.22 & 4.57 \\
\hline
\end{tabular}

*Means followed by the same letter do not differ statistically by the Tukey's test (0.05). Averages followed by \pm standard deviation; Coefficient of variation (CV) of the observed parameters

in agreement with those cited, where the high temperature and low RH right after harvest resulted in higher weight losses throughout storage, when compared to grapes stored after harvest under the recommended temperature and $\mathrm{RH}$ conditions.

The contents of soluble solids were higher in fruits exposed to high temperature and low RH only after 30 days of refrigerated storage plus 7 days at $25^{\circ} \mathrm{C}$ (Table 3). Thus, it was observed that the exposure of the fruits to high temperature and low RH promoted a higher fruit dehydration, concentrating the SS (Table 3). The corresponding data corroborate those described by Brackmann et al. (2002), with treatments that ranged from $-1{ }^{\circ} \mathrm{C}$ to $+0.5^{\circ} \mathrm{C}$, and $\mathrm{RH}$ from 93 to $97 \%$, storing the varieties Tardia de Caxias and Dona Zilá for up to 35 days, plus exposure to $20^{\circ} \mathrm{C}$ for two days. It was observed that after storage, there was no statistical difference in the SS content; however, after fruit exposure to $20^{\circ} \mathrm{C}$, there was statistical difference for the varieties.

Fruits exposed to high temperature and low RH prior to the refrigerated storage presented higher rachis dry matter levels at 14,30 , and $30+7$ days of storage, along with higher berry dry matter at $30+7$ days of refrigerated storage, compared to fruits stored under refrigeration immediately after harvesting (Table 3). As a significant part of the weight loss in fruit is due to water loss, the higher rachis and berry dry matter content in fruits exposed to high temperature and low RH soon after the harvest are due to the higher fruit dehydration during storage. These results suggest that the exposure of the fruit to high temperature and low RH immediately after harvest stimulated rachis and berry dehydration. This possibly caused modifications in the epidermis of these tissues, resulting in higher water loss rate throughout storage.

Further studies were carried out with Italia grapes, stored at $1{ }^{\circ} \mathrm{C}$ and $90 \% \mathrm{RH}$ for 15 days, which were performed in three replicates. After the storage period, the dry mass of the rachis and berry were analyzed. There was a statistical difference in the first repetition in relation to the others, regarding the rachis dry matter, which corroborates the data presented in Table 3 , where the TER storage resulted in higher rachis dry mass, owing to exposure to high temperature. As for the berry, there was no statistical difference between the three replicates of the storage periods (Rodrigues et al., 2011).

Thus, it is evident that the high temperature conditions in the packing houses had negative repercussions on grape quality. In this type of installations, it is necessary to use roofs with less energy transmission, apply double coating over the masonry, utilize ceramic blocks, orientate the installation east-west, provide surrounding vegetation, and use well-placed living walls. All the cited items can help improve the temperature conditions of these environments, promoting a longer period of consumption for the grapes from the São Francisco Valley region.

\section{Conclusions}

1. The studied packing house presented environmental conditions of high temperature and low $\mathrm{RH}$, affecting certain quality attributes of the fruit.

2. Building techniques and/or refrigeration of the fruit selection area inside the packing house can improve the quality of table grapes produced in the region of the São Francisco Valley, Brazil.

\section{Literature Cited}

Albertini, S.; Miguel, A. C. A.; Spoto, M. H. F. Influência de sanificantes nas características físicas e químicas de uva Itália. Food Science and Technology, v.29, p.504-507, 2009. https://doi.org/10.1590/ S0101-20612009000300007

AOAC - Association of Official Analytical Chemistry. Official methods of analysis of the Association of Official Analytical Chemistry. 18.ed. Gaitherrsburg: AOAC, 2012. 
Brackmann, A.; Vizzotto, M.; Ceretta, M. Qualidade de uvas cvs. Dona Zilá e Tardia de Caxias sob diferentes condições de armazenamento. Revista Ciência e Agrotecnologia, v.26, p.1019-1026, 2002.

Champa, W. A. H.; Gill, M. I. S.; Mahajan, B. V. C.; Bedi, S. Exogenous treatment of spermine to maintain quality and extend postharvest life of table grapes (Vitis vinifera L.) cv. flame seedless under low temperature storage. LWT - Food Science and Technology, v.60, p.412-419, 2015. https://doi.org/10.1016/j.lwt.2014.08.044

Chitarra, M. I. F.; Chitarra, A. B. Pós-colheita de frutos e hortaliças: Fisiologia e manuseio. 2.ed. Lavras: UFLA, 2005. 738p.

Gibbon, J. M. Some observations of temperatures and cooling rates of vegetables in commercial cold stores. Journal of Agricultural Engineering Research, v.17, p.332-337, 1972. https://doi. org/10.1016/S0021-8634(72)80039-8

Guillou, R. Some engineering aspects of cooling fruits and vegetables. Transactions of the ASAE, v.1, p.938-942, 1958.

Lima, M. A. C. O Conhecimento da uva de mesa AGEITEC. Brasília, DF: Embrapa Informação Tecnológica; Petrolina, PE: Embrapa Semiárido, 2016.

Lukiantchuki, M. A.; Shimomura, A. R. P.; Silva, F. M. da; Caram, R. M. Sheds extratores e captadores de ar: Influência da geometria e da dimensão das aberturas no desempenho da ventilação natural nas edificações. Ambiente Construído, v.16, p.83-104, 2016. https:// doi.org/10.1590/s1678-86212016000100062

Mascarenhas, R. de J.; Guerra, N. B.; Aquino, J. de S.; Leão, P. C. de S. Qualidade sensorial e físico-química de uvas finas de mesa cultivadas no submédio São Francisco. Revista Brasileira de Fruticultura, v.35, p.546-554, 2013. https://doi.org/10.1590/S0100-29452013000200025

Matheus, C.; Caetano, F. D. N.; Morelli, D. D. de O.; Labaki, L. C. Desempenho térmico de envoltórias vegetadas em edificações no Sudeste brasileiro. Ambiente Construído, v.16, p.71-81, 2016. https://doi.org/10.1590/s1678-86212016000100061

Mitchell, F. G. Cooling of horticultural commodities. In: Kader, A. A. Postharvest technology of horticultural crops. 3.ed. Division of Agriculture and Natural Resources. Davis: University of California, 2002. 295p.

Nunes, M. C. N.; Brecht, J. K.; Morais, A. M. M. B.; Sargent, S. A. Physical and chemical quality characteristics of strawberries after storage are reduced by a short delay to cooling. Postharvest Biology and Technology, v.6, p.17-28, 1995. https://doi. org/10.1016/0925-5214(94)00048-W

Pinto, J. A. V.; Schorr, M. R. W.; Thewes, F. R.; Ceconi, L. D.; Both, V.; Brackmann, A.; Fronza, D. Relative humidity during cold storage on Postharvest quality of 'Niagara Rosada' table grapes. Ciência Rural, v.45, p.386-391, 2015. https://doi.org/10.1590/0103-8478cr20130307
Ribeiro, T. P.; Lima, M. A. C. de; Souza, S. O. de; Araujo, J. L. P. Perdas pós-colheita em uvas de mesa registradas em casas de embalagem e em mercado distribuidor. Revista Caatinga, v.27, p.67-74, 2014.

Rodrigues, A.; Araujo, J. P. C. de; Girardi, E. A.; Scarpare, F. V.; Scarpare Filho, J. A. Aplicação de $\mathrm{AG}_{3}$ e CPPU na qualidade da uva 'Itália' em Porto Feliz-SP. Revista Brasileira de Fruticultura, v.33, p.1-7, 2011. https://doi.org/10.1590/S010029452011005000033

Sabir, F. K.; Sabir, A. Quality response of table grapes (Vitis vinifera L.) during cold storage to postharvest cap stem excision and hot water treatments. International Journal of Food Science and Technology, v.48, p.999-1006, 2013. https://doi.org/10.1111/ijfs. 12052

Santos, L. de S.; Ribeiro, V. G.; Lima, M. A. C. de; Souza, E. R.; Shishido, W. K. Influência do ácido giberélico na fisiologia e qualidade da videira cv. Sweet Celebration ' no submédio São Francisco. Revista Brasileira de Fruticultura, v.37, p.827-834, 2015. https://doi.org/10.1590/0100-2945-232/14

Silva, F. de A. S. e; Azevedo, C. A. V. de. The Assistat Software version 7.7 and its use in the analysis of experimental data. African Journal of Agricultural Research, v.11, p.3733-3740, 2016. https://doi. org/10.5897/AJAR2016.11522

Silva, R. S. da; Silva, S. de M.; Dantas, A. L.; Mendonça, R. M. N.; Guimarães, G. H. C. Qualidade de uva 'Isabel' tratada com cloreto de cálcio em pós-colheita e armazenada sob atmosfera modificada. Revista Brasileira de Fruticultura, v.34, p.50-56, 2012. https://doi. org/10.1590/S0100-29452012000100009

Soares, J. M.; Leão, P. C. de S. A vitivinicultura no Semiárido brasileiro. Brasília, DF: Embrapa Informação Tecnológica; Petrolina, PE: Embrapa Semiárido, 2009. 756p.

Sullivan, G. H.; Davenport, L. R.; Julian, J. W. Precooling: Key factor for assuring quality in new fresh market vegetable crops. In: Janick, J. (ed.). Progress in new crops. Arlington - VA: ASHS Press, 1996. p.521-524.

Teruel, B. J. M. Tecnologias de resfriamento de frutas e hortaliças. Revista Brasileira de Agrociencia, v.14, p.210-235, 2008.

Vasconcelos, O. C. M. Microclima do setor de seleção de casas de embalagens de uva no Vale do Submédio São Francisco. Petrolina: UNIVASF, 2015. 89p. Dissertação Mestrado

Wu, Z.; Yuan, X.; Li, H.; Liu, F.; Wang, Y.; Li, J.; Cai, H.; Wang, Y. Heat acclimation reduces postharvest loss of table grapes during cold storage - Analysis of possible mechanisms involved through a proteomic approach. Postharvest Biology and Technology, v.105, p.26-33, 2015. https://doi.org/10.1016/j. postharvbio.2015.03.012 